\title{
DIÁLOGO DE OBRAS: INTERTEXTOS DE ASTURIAS E DE GREENE EM VERISSIMO
}

\section{DIALOGUE OF WORKS: INTERTEXTS OF ASTURIAS AND GREENE IN VERISSIMO}

\author{
Daniel Castello Branco Ciarlini ${ }^{1}$ \\ Universidade Federal do Rio Grande do Sul
}

\section{RESUMO}

A relação dos intertextos que se operam nas obras de Ángel Miguel Asturias e de Graham Greene com as de Erico Verissimo é do que se ocupa este artigo, cujos objetos são O senhor presidente, $O$ americano tranquilo e $O$ senhor embaixador e $O$ prisioneiro, respectivamente. As relações entre os dois romances do escritor gaúcho também são motivadas pela mesma perspectiva, cujo foco recai nas visadas ideológicas do próprio autor em sua fabulação e modos de denúncia dos regimes totalitários e do imperialismo norte-americano. Para tal fim, válido foi observar as formas intertextuais definidas por Laurent Jenny (1967), bem como as observações acerca do gênero romance na América Latina propostas por Doris Sommer (2009) e Otto Maria Carpeaux, e do imperialismo, por Edward Said (2009).

PALAVRAS-CHAVE: Verissimo; América Latina; Intertexto; Imperialismo.

\begin{abstract}
The relation of the intertexts presented in the works of Ángel Miguel Asturias and Graham Greene with those of Erico Verissimo is what this article talks about, the books are El señor presidente, The quiet american and $O$ senhor embaixador and $O$ prisioneiro, respectively. The relations between the two novels of the Brazilian writer are also motivated by the same perspective, whose focus remains on the author's own ideological aims in his fabulation and ways of denunciation of the totalitarian regimes and US imperialism. To do the analysis, we used the intertextual forms defined by Laurent Jenny (1967), as well as the observations about the novel genre in Latin America proposed by Doris Sommer (2009) and Otto Maria Carpeaux, and imperialism, by Edward Said (2009).
\end{abstract}

KEYWORDS: Verissimo; Latin America; Intertext; Imperialism.

\section{Intertextualidade e construção literária}

Em “A estratégia da forma”, ensaio publicado na revista Poética (1979), Laurent Jenny analisa o processo da intertextualidade como essencial à compreensão de uma obra literária, posto que esta sem aquela "seria muito simplesmente incompreensível, tal como a palavra duma língua ainda desconhecida" (JENNY, 1979, p. 5). Logo, "deve a intertextualidade situar-se

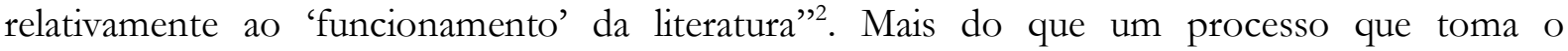
predecessor como norte - e a partir dele atua em uma conjuntura discursiva em diálogo -, Jenny

\footnotetext{
${ }^{1}$ Mestre em Letras pela Universidade Estadual do Piauí e doutorando em Estudos de Literatura pela Universidade Federal do Rio Grande do Sul. É bolsista CAPES. E-mail: danielcastellobranco@hotmail.com.

2 Idem, ibidem, p. 6
} 
entende que, mesmo quando negada a relação direta com o predecessor, caracterizando-se, por fim, "por não ter nenhum traço comum com os gêneros existentes, longe de negar a sua permeabilidade ao contexto cultural, ela confessa-a justamente por essa negação", afinal, "Fora dum sistema, a obra é impensável"’3. Tal sistema, na visão de Tzvetan Todorov (2006, p. 20), situa-se em uma rede de relações, afinal "a obra literária não é jamais 'original', ela participa de uma rede de relações entre ela mesma e as outras obras do mesmo autor, da mesma época, do mesmo gênero".

Todorov, portanto, permite ampliar, de alguma forma, esse posicionamento de Jenny, que se concentra em uma perspectiva inerente às obras, ao pensar que haja, ainda entre elas, uma conexão colhida em um nível extraliterário, quando essas refletem fatos além do texto, como os políticos. Tal visada, porém, não é nova: já vinha sendo abordada por Jan Mukarovsky, do Círculo Linguístico de Praga, quando em importante ${ }^{4}$ ensaio revela que "Sempre houve, é verdade, empréstimos de literatura para literatura, às vezes propiciados seja por uma comunidade de ideias, seja por acontecimentos de ordem política (cruzada)" (MUKAROVSKY, 1978, 310, grifo nosso). Importa destacar que Edward Said, elevando essa ideia ao nível de cultura, afirma algo muito parecido em Cultura e imperialismo (2011), ao declarar a história de todas as culturas como uma história de empréstimos culturais, justamente porque as culturas não são impermeáveis e próprias de um povo, mas resultados de apropriações, experiências comuns e interdependências de todo tipo.

No caso específico deste trabalho, aqui orientado pelo viés de Jenny e Mukarovsky, ocorre uma espécie de convergência entre literaturas de diversos países, que abordam, por uma razão relativamente próxima, temáticas específicas, problematizando situações comuns, como foi o caso, na América Latina, dos romances de ditadura; isso conduz, aplicado ao romance, ao que Said denomina de "norma universal" e Doris Sommer (2009) acredita sustentar a existência de um "gênero internacional". Aliás, é esse um ponto que permitiu aos países latino-americanos se diferenciarem das produções romanescas europeias, como ainda acrescenta a estudiosa, com características que tomam, por exemplo, o amor não apenas como um aspecto de cunho sentimental, mas, metaforicamente, como forma de educação cívica. Isso explica por que, na prática, os romances "funcionavam como manuais, intencionalmente escandidos em longos períodos de modo a dissuadir pouco a pouco os leitores das paixões inúteis e a encorajar neles o desejo produtivo" (SOMMER, 2009, p. 315). Reflexo da própria formação desses homens de letras, Sommer informa que parte significativa deles era formada por homens públicos, o que incidia diretamente na conduta de suas escritas e ideologias frente ao produto literário:

\footnotetext{
Os romances eram escritos pelos mesmos que construíam as nações (generais, futuros presidentes, legisladores) durante a trégua entre uma guerra civil e outra, ou quando a paz permitia reparar os danos e convidava os cidadãos (virtuais) a depor as armas a fim de que se tornassem cidadãos reais, capazes de dar vida a uma nação composta por inúmeras famílias (SOMMER, 2009, p. 314),
}

daí que "os escritores e os leitores dos romances nacionalistas latino-americanos estavam de fato construindo uma relação alegórica entre narrações pessoais e narrações políticas" (SOMMER, 2009, p. 323).

Vê-se explicado o fato de que, na América Latina, "os romances ajudaram as constituições e os códigos civis de definição dos costumes modernos" e, diferentemente dos romances ingleses, "se valem da urdidura para fabricar um tecido grosso de homens capazes também de sentimentalismo" (SOMMER, 2009, p. 319). Tal fenômeno ocorre devido à intertextualidade, responsável que é pela reativação e transformação de sentidos: "A

\footnotetext{
${ }^{3}$ Idem, ibidem, p. 5.

${ }^{4}$ Ref. "Obrigações da ciência literária em relação à literatura mundial contemporânea".
} 
intertextualidade é pois máquina perturbadora. Trata-se de não deixar o sentido em sossego - de evitar o triunfo do "clichê' por um trabalho de transformação" (JENNY, 1979, p. 45).

São essas transformações, essas transcendências, que Edward Said percebe como essenciais e dignas de apreciação nas contribuições deixadas pelos escritores e intelectuais que estão fora do circuito europeu, justamente por suas diferentes experiências no campo estético e, por que não, contextual. Afinal, advêm daí novas proposituras no campo dos bens simbólicos, para se utilizar, aqui, da base conceitual de Bourdieu.

\begin{abstract}
De um modo totalmente novo na cultura ocidental, as intervenções de estudiosos e artistas não europeus não podem ser descartadas ou silenciadas e, além de constituírem parte integrante de um movimento político, também são, de muitas maneiras, a imaginação e a energia intelectual e figurativa do movimento, exitosamente inspiradoras, revendo e repensando o terreno comum a brancos e não brancos (SAID, 2011, p. 332-3).
\end{abstract}

Da convergência das literaturas, de que se tratou aqui, que representa, pelo menos na realidade latino-americana, um elo, o que por si poderia tornar lógica uma construção unívoca entre os diversos produtores, nada "impede em absoluto a multiplicidade das suas manifestações" (MUKAROVSKY, 1978, p. 311):

No momento em que inúmeras literaturas até então desconhecidas ou mesmo inexistentes passam a integrar a comunidade das literaturas nacionais e em que, consequentemente, certas tradições e certos métodos artísticos estranhos uns aos outros começam a encontrar-se e a aperceber-se da sua mútua presença, as manifestações literárias tornam-se, ao contrário, mais variadas e diferenciadas do que nunca ${ }^{5}$.

O que permite tal operação advém do que Bloom designa como a "angústia da influência", que, como observa Jenny, leva o seguidor "a modificar os modelos que o seduzem, segundo múltiplas figuras" (JENNY, 1979, p. 8). Daí o fato de as histórias de fundação na América Latina destoar do romance europeu.

Essa ideia de "histórias de fundação na América Latina" foi também admitida por Otto Maria Carpeaux, que visualizou a inter-relação da literatura latino-americana e das ditaduras, posto terem "quase a mesma idade" (CARPEAUX, 1967, p. 12). Não seria difícil entender e analisar que esses romances sejam políticos e revolucionários, instituídos por um contexto próprio nessa parte do globo. Quanto a esse aspecto, ainda Carpeaux observa "O romance político [como um] gênero que tem sua dignidade especial", no que tange ao conjunto de produções literárias latino-americanas do período, que denunciaram os regimes totalitários, "Em todas essas obras aparece a Política como algo que subjuga o homem e que os faz sofrer. São romances de derrota: dos homens e das ideologias que representam os acreditam representar" Nesse ponto, tanto $O$ senhor presidente quanto $O$ senhor embaixador dialogam entre si, pois ressaltam essa derrota que, depreende-se de Carpeaux, é dupla: a do homem subjugado pelo próprio homem e a das falidas ideologias que o perseguem. Decorrem daí seus desfechos pessimistas, revestidos de uma fachada liberal.

A intertextualidade, portanto, tem uma importância ímpar na construção de sentidos em uma obra. Ela, por si, é responsável pela significação do texto a partir de outros textos, que o legitimam, afinal "A verdade literária, como a verdade histórica, só podem constituir-se na multiplicidade dos textos e das escritas - na intertextualidade" (JENNY, 1979, p. 47). Assim sendo, "o livro não é senão um sistema de variantes, e nunca podemos apoiar-nos numa versão

\footnotetext{
${ }^{5}$ Idem, ibidem.

${ }^{6}$ Idem, ibidem, p. 11.
} 
autêntica da historieta narrada", posto que esta se forma de um circuito de obras responsáveis pelo seu sentido sem o qual não haveria maneira de compreendê-la e, portanto, significá-la.

\section{Romances de ditatura e liberdade: simetrias entre Asturias e Verissimo}

No ano de 1976, Milton Friedman conquistou o prêmio Nobel de Economia pelo livro Capitalismo e liberdade. Dentre as diversas análises que versam sobre a conduta liberalista na economia e na política, o cientista entendia que

\footnotetext{
se o poder econômico é adicionado ao poder político, a concentração [de poder] se torna praticamente inevitável. De outro lado, se o poder econômico for mantido separado do poder político e, portanto, em outras mãos, ele poderá servir como controle e defesa contra o poder político (FRIEDMAN, 1977, p. 24).
}

Tal análise leva em consideração a forte ameaça que representa à liberdade o poder político que concentra o poder econômico, ainda quando os dois estejam "nas mãos de um monarca, de um ditador, de uma oligarquia ou de uma maioria momentânea" "Mesmo se os homens que controlam este poder estejam, inicialmente, repletos de boa vontade e mesmo que não venham a ser corrompidos pelo poder, este formará e atrairá homens de tipos diferentes" ". Eis uma das razões de, na América Latina, o liberalismo ter sido uma argumentação econômica, considerando "a economia no seu significado ordinário de gestão das relações familiares e domésticas" (SOMMER, 2009, p. 317). Tal argumento, somado ao de democracia, se reflete ao longo das narrativas de ditadura do período, que, na voz de revolucionários, em posturas de liberdade, e dos próprios ditadores, servem a discursos políticos com o fim de manutenção do poder, como ocorre nos bailes presidenciais retratados por Asturias em $O$ senhor presidente, em que o chefe-maior é, de modo hiperbólico, considerado "Presidente Constitucional da República, Chefe do Partido Liberal, Benemérito da Pátria, Protetor das mulheres desvalidas, da criança e da instrução" (ASTURIAS, 1967, p. 105).

Com esse nível de reflexão é possível analisar alguns pontos intertextuais nos dois romances O senhor presidente (1946), de Miguel Ángel Asturias, e O senhor embaixador (1965), de Erico Verissimo, ambos de ditatura, que problematizam os poderes totalitários em regiões da América Latina?.

$\mathrm{Na}$ obra de Asturias, por exemplo, observa-se toda uma cadeia de corrupção relacionada ao governo com as oligarquias rurais em face da exploração de empresas estadunidenses no território do país, supostamente a Guatemala ${ }^{10}$; em $O$ senhor embaixador, por sua vez, são ainda os interesses estadunidenses nas terras fictícias de Sacramento que constroem a base dos regimes totalitários os quais assumem posturas revolucionárias ao tomar o poder. Sacramento, embora sendo um país imaginário criado por Erico, tem alguns elementos que merecem ser admitidos como chaves para a leitura de uma suposta ironia legada pelo autor: ao esboçar o mapa da fictícia ilha, o desenho aponta, segundo informa Barros (1996, p. 1), a partir de Flávio Loureiro Chaves, para "a forma exata do Brasil", além do enredo representar "uma paródia da revolução de Fidel Castro em Cuba" (CHAVES apud BARROS, 1996, p. 1).

Além disso, e dentro da estrutura de poder político e econômico problematizado nas duas obras, é em O senhor embaixador que os complôs de corrupção se formam diante da ignorância do chefe-maior, o presidente. Elucidativa é a pré-história da narrativa, que desvenda o caso do

\footnotetext{
7 Idem, ibidem, p. 23.

8 Idem, ibidem, p. 12.

9 As edições utilizadas para análise do presente trabalho são: para o primeiro, 1967; para o segundo, 2009.

${ }^{10}$ Em sua introdução ao romance, em 1967, Otto Maria Carpeaux localiza o enredo como sendo na Guatemala: "O ambiente do romance é, inconfundivelmente, a Guatemala no tempo da ditadura de Cabrera” (CARPEAUX, 1967, p. 10).
}

Revista do GELNE, Natal/RN, Vol. 20 - Número 1: p. 101-112. 2018 
presidente Chamorro, vítima das manobras de corrupção da própria esposa, D. Rafaela, e de uma série de outros mandatários do governo. Chamorro, ludibriado, assiste a uma realidade distinta da que ocorre dentro de seu país, posto que partem de seus secretários e de sua esposa a construção fictícia de um governo e de um povo feliz e receptivo ao seu presidente, quando na realidade este é visto como ditador e carrasco, frente a uma miserável população. Não se pode, porém, determinar a mesma operação em $O$ senhor presidente. Tem-se nessa narrativa um caso de corrupção instaurada e comandada pelo próprio chefe do poder executivo. Todavia, corre também em paralelo um modus operandi às cegas do presidente, comandado por seu Auditor de Guerra, que parece desempenhar arbitrariamente métodos de tortura a fim de obter informações, como fizera com Fedina Rodas, para que informasse o paradeiro de Canales; métodos, inclusive, desconhecidos do próprio presidente, além do fato de construir raciocínios e acusar indistintamente seus desafetos, sem o crivo do chefe-maior, e manter negócios obscuros ao governo, a citar o que mantinha com Ção Dente de Ouro, ao vender prisioneiras para o prostíbulo "O Doce Encanto".

Há tanto em $O$ senhor presidente quanto em $O$ senhor embaixador e, ainda, em $O$ prisioneiro, este também de Erico Verissimo, a retratação dos interesses estrangeiros em terras alheias, daí a sua interferência direta nas conduções políticas encerradas nas nações vitimadas pelos regimes totalitários. No caso de $O$ senhor presidente os interesses estrangeiros se relacionavam aos interesses de uma elite rural, financiadora dos governos totalitários que se instalavam; já em O prisioneiro, a guerra em defesa da democracia contra os avanços da guerrilha comunista esconde outras estruturas de poder que correm em paralelo aos interesses eminentemente políticos. Nesta obra, é no diálogo entre a professora e o tenente que notamos a denúncia: "será preciso lembrar-lhe, tenente, da existência de 'grupos de elite' que têm os olhos, os interesses e os planos voltados para as riquezas minerais e vegetais desta região?", e prossegue, citando os produtos explorados pelo interesse estrangeiro: "Bauxita, ferro, tungstênio, resinas, óleos, sisal, arroz, chá..." (VERISSIMO, 1967, p. 76). Tais grupos, também são vistos em O senhor embaixador, representados pela elite rural, a serviço das empresas estadunidenses, bem como a prostituição infantil em Puerto Esmeralda e o tráfico de cocaína, de heroína e de maconha como negócios mais rendosos do país.

Apesar de abordar temáticas outras paralelas como o racismo, o eixo que mantém a narrativa de $O$ senhor embaixador, como um todo, tem forte apelo aos problemas políticos na América Latina, fato que se repete, como lembra Bordini, com os demais escritores brasileiros e latino-americanos da época, cujos "interesses literários voltavam-se para a participação política e eventualmente revolucionária” (BORDINI, 2004, p. 213). Tal percepção, aliás, fora reconhecida por Erico, como assinala Minchillo (2015, p. 224):

Erico Verissimo admitia que O Senhor Embaixador tinha cunho deliberadamente político, ainda que não partidário. Logo nas primeiras páginas do romance, o jornalista William Godkin, que muitos anos antes havia feito uma reportagem sobre Juventino Carrera enquanto este era um combatente revolucionário, pergunta-se se aquilo que se considera fato não seria apenas a ponta de um iceberg, cuja parte invisível 'está submersa nas águas dum turvo oceano de interesses políticos e econômicos, egoísmos e apetites nacionais e individuais'.

O senhor embaixador, nesse diapasão, chega a adotar uma postura de denúncia, principalmente na fala do professor Leonardo Gris, na sede da American University, sob o título "Duras verdades sobre a República do Sacramento". O texto ficcional, ao adotar o recurso do gênero palestra, e após as considerações acerca do regime totalitário do ditador sacramentenho Carrera e seu envolvimento no mercado negro das drogas - corroborado por Gabriel Heliodoro, embaixador de Sacramento nos EUA -, revela, em tom anticlerical, o envolvimento do arcebispo da fictícia nação, D. Pánfilo, com o governo de Carrera, bem como os EUA como apoiador de 
ditadores ("cruéis e desonestos como Trujillo, Somoza e Batista" ") por razões econômicas. Alude a isso o trecho em que a personagem declara a inocência do povo estadunidense quanto às ações de seus governantes em terras alheias, o que deixa entrever, inclusive, certo controle do executivo sobre a própria imprensa:

Na minha opinião, só uma coisa iguala a boa vontade deste povo norte-americano: é a sua inocência. Tendes os mais modernos e interessantes jornais do mundo e no entanto sois uma nação mal informada, principalmente no que diz respeito aos outros países e povos. Não podeis compreender como é que, gastando bilhões de dólares na ajuda a governos estrangeiros, os Estados Unidos, em vez de fazerem amigos, estão comprando inimigos... (VERISSIMO, 2009, p. 234).

E mais adiante o conferencista denuncia os paradoxos do ideal de liberdade, igualdade e fraternidade, visto com ironia na obra como "grande sonho", e do modo de vida dos Estados Unidos. Os dois contribuem para a instalação de regimes totalitários, sem os quais a sociedade norte-americana não poderia manter o seu alto padrão de vida. Assim expõe Gris na palestra:

\begin{abstract}
Viveis uma grande contradição. Alimentais um grande sonho de liberdade, igualdade e fraternidade, mas a experiência tem mostrado que, se fordes absolutamente fiéis a esse sonho, não só na teoria como também na prática, não podereis manter o vosso alto e crescente padrão de vida. Porque me parece que quando existem países, grupos ou indivíduos extremamente ricos, é porque esse enriquecimento se fez à custa de outros países, grupos e indivíduos que tiveram de permanecer extremamente pobres (VERISSIMO, 2009, p. 236).
\end{abstract}

A questão implica certa mutualidade, por isso merece alusão como essencial para se compreender, pelo menos nesse nível, a tessitura do tipo de romance com o que Erico se identificava nessa fase, cuja relação, tão evidente, dos Estados Unidos para com as republiquetas da América, as banana republics, talvez revele um intertexto importante:

Isso parece significar na economia simbólica do romance que os países latinoamericanos só possa ser integralmente compreendidos a partir do coração do império norte-americano, sem o qual a vontade nacional das outras repúblicas americanas dificilmente se realiza e se sustenta (MINCHILLO, 2009, p. 227).

Aliás, tem-se aqui uma relação também simétrica entre Erico e Asturias, porque em ambas as representações de sistemas totalitários há, da parte de seus ditadores, algum temor em perder o apoio de Washington. É válido admitir que a percepção de Gris em sua palestra adveio da própria experiência de Erico Verissimo quando em 1953 assumiu o cargo de diretor do departamento de assuntos culturais da União Pan-Americana (UPA), nos Estados Unidos, e se inteirou dos fatos que se desenrolavam entre o governo norte-americano e as repúblicas latinoamericanas. Como observa Minchillo (2009, p. 207), nessa esfera

Erico deu prosseguimento a sua atuação como proeminente articulador da esfera artística intelectual brasileira com a norte-americana e, em alguma escala, com a hispano-americana, incrementando sua inserção numa extensa rede pessoal e institucional dos Estados Unidos e da América Latina.

11 VERISSIMO, 2009, p. 235. 
A visão de Gris não parece destoar da do próprio Erico, quanto ao juízo a respeito da sociedade estadunidense, como deixa entrever Minchillo (2009, p. 209): "Erico deixa transparecer certa indisposição com a sociedade norte-americana, ou ao menos com setores dela", isso porque em sua construção ficcional, ou mesmo em sua base ideológica, "Erico Verissimo manteve-se fiel a seus princípios, combatendo o totalitarismo, em qualquer de suas expressões" (MINCHILLO, 2009, p. 211). Confirma essa informação de engajamento o conjunto de cartas de Erico que, em 1996, levou a público o professor Flávio Loureiro Chaves, de sua correspondência íntima com o escritor de $O$ senhor embaixador, como assevera: "Erico nunca pertenceu a nenhum partido político e era muito malvisto pelos comunistas do PC, por sua postura independente. Mas nas cartas demonstrava uma coerência política impressionante: era contra qualquer repressão e tratava com raiva certas ações dos governos militares" (CHAVES apud BARROS, 1996, p. 1).

Esse combate, ou antes postura de denúncia, aos regimes totalitaristas, que levou Chaves (1996, p. 1) a reconhecer o escritor gaúcho como "uma das duas grandes vozes da consciência nacional" - sendo a primeira a do frei dominicano Tito Alencar, torturado no Brasil na época da ditadura -, está exposto tanto em $O$ senhor embaixador quanto em $O$ prisioneiro, cujos conflitos incidem diretamente na representação do tema da crise de identidade - prova disso são as personagens porta-vozes do próprio autor, como o já citado Leonardo Gris, e em O prisioneiro, a professora, quando diz com todas as letras, em diálogo com o tenente: "Saiba que detesto qualquer totalitarismo, seja qual for seu disfarce ou pseudônimo" (VERISSIMO, 1967, p. 69).

A ideia que se pode depreender das denúncias de Gris acerca da relação dos Estados Unidos com as republiquetas latino-americanas, fato que se constata em outros romances de denúncia, a citar o também aqui estudado $O$ senhor presidente, é confirmada por Maria da Glória Bordini (2004, p. 214), quando informa que, ao se aventurar na escrita de O senhor embaixador, Erico Verissimo "Queria com o livro estudar um modelo das repúblicas latino-americanas dependentes dos Estados Unidos e do intelectual na política militante e em uma revolução"; fato este que se pode averiguar em personagens como Pablo Ortega.

Se o fator de ordem política é o ponto simétrico principal entre a obra de Verissimo e a de Asturias, importante é observar outros pontos que se operam nessa conjuntura entre os romances, que apontam como principais adversários de regimes totalitários à base constituída por intelectuais dentro de universidades: professores, estudantes ou mesmo bacharéis. E somente isso explica a razão de tanto em $O$ senhor presidente quanto em $O$ senhor embaixador, ser as vozes silenciadas e perseguidas, posto representarem o grito de consciência e liberdade. No campo do primeiro livro, a representação recai diretamente para duas figuras, o bacharel Abel Carvajal, que é preso e acusado injustamente da morte do coronel Sorriente; e do estudante, cuja história não vem a ser contada na narrativa, embora seja, de todos os perseguidos, aquele que representa o maior impulso de luta contra a opressão. Apesar da obscuridade lançada sobre o seu passado, o estudante, personificação do ideal de liberdade (daí, talvez, não ter nome próprio), é, de todas as personagens de Asturias, a que foi construída com maior otimismo e perseverança, e como lembra Carpeaux (1967, p. 13), "Todos os revolucionários presos sucumbem, no romance, só um sobrevive: um estudante".

Já no livro de Verissimo, a figura do intelectual se volta para as personagens Júlio Moreno e Leonardo Gris, líderes da primeira rebelião que põe fim ao governo do ludibriado Chamorro, implantando em Sacramento a justiça social, até serem depostos por Carrera, que retoma o governo ditatorial. Há, porém, nessa obra, uma terceira personagem, que se ergue e representa um elo entre liberdade e engajamento, o intelectual Pablo Ortega, cuja consciência democrática vai se solidificando e alcança o ápice com a sua participação direta na revolução de Barrios, pondo fim ao regime ditatorial de Carrera. Aliás, Ortega faz o típico herói problemático latinoamericano, que na concepção de Sommer (2009, p. 329), "são protagonistas sensatos, ingênuos e em contínuo amadurecimento". Pablo, em suma, "corresponde ao intelectual inassimilável em todos os lugares', conforme comentou Jean-Paul Sartre a respeito do intelectual burguês que, 
afastando-se criticamente de sua classe, não pode contudo ser confundido com as classes populares" (MINCHILLO, 2009, p. 237).

A partir desse contexto, é possível, aqui, admitir o intelectual resistente como uma espécie de arquétipo, como quer Laurent Jenny, que determina de modo intertextual as obras em destaque, representando um modo implícito de construção que tende, da parte de Verissimo, a realizar, com alguma transformação, a mesma operação, em simetria, do constructo de Asturias quando do papel do sujeito intelectual diante do totalitarismo.

Ortega é, nesse ponto, a transformação de uma narrativa para outra, posto ser uma das personagens que vive crises de consciência profundas, sendo a primeira a que é alimentada pela mãe, que o chantageia com os problemas de saúde do pai, ganhando assim controle sobre o destino do filho; e a segunda, talvez a mais profunda, porém menos frágil, sua ajuda a Barrios a subir ao poder, do que se arrepende ao perceber que este não instaura os ideais nobres esperados da revolução, tornando-se mais um chefe de governo totalitário, cujos desmandos são divididos com Valencia. Uma vez trabalhando (embora desgostoso) para a embaixada de Sacramento gerenciada por Gabriel Heliodoro, comparsa de Carrera, demonstra, desde o princípio, simpatia por Leonardo Gris, cujas denúncias nos EUA contra o governo sacramentenho refletem, na realidade, parte de suas próprias ideias.

\section{Romances de guerra: convergências e divergências entre Greene e Verissimo}

Com exceção de Asturias, que pouco expõe a pré-história de suas personagens, há um ponto que permite conectar as obras de Verissimo entre si bem como com a de Greene: o uso do flashback, apelo à memória, a fim de narrar os fatos da fábula. Tal recurso, porém, como admite Jenny ao reler Borges, antes de simples memórias, permite reconhecer que "O olhar intertextual é então um olhar crítico", isso porque explicita também as tomadas de posição ideológica da narrativa e, não por acaso, refletem as problemáticas-chaves dos textos ficcionais. É o que se percebe, por exemplo, em $O$ prisioneiro, quando as memórias do tenente, personagem principal, conduzem ao tema do racismo ${ }^{12}$, fomentado pela sociedade de seu país de origem que, embora ocultado, reconhece-se como sendo os EUA. Diferenças de "raça" e ideologia política, portanto, são fatores que conduzem, pelo menos ao relacionarmos a obra de Verissimo a de Greene, os textos a diálogos intertextuais. Enquanto em $O$ americano tranquilo temos uma guerra colonial na Indochina, em $O$ prisioneiro, a guerra é imperialista no Vietnã, além do fato de ambas estarem ligadas, ainda, a fatores de forças estrangeiras que interferem na situação política dos países em que se desenvolvem as tramas no sudeste asiático. Nesse último, Erico, em uma postura engajada, continua com seu projeto de denúncia, através da ficção, de regimes totalitários e do imperialismo com os quais conviveu em seu tempo. Como observa Minchillo (2009, p. 244), em O prisioneiro, "Erico Verissimo escrevia, assim, uma denúncia dos efeitos do neocolonialismo, assumindo com essa escolha temática posição de ponta no debate dos assuntos internacionais dos anos 1960".

A proximidade temática da obra de Verissimo com a de Greene se dá pela própria postura do escritor gaúcho em apreciar a obra do escritor inglês. Contemporâneos, Verissimo, ao que tudo indica, alimentava certa estima pelo autor de $O$ americano tranquilo, cujo contato não se efetivara apenas em termos estéticos como também pessoalmente, é o que indica o próprio Erico em carta a Flávio Loureiro Chaves. O encontro com Greene, como ocorrera com outros nomes da literatura mundial de sua época, segundo conta Chaves, não foi dos melhores, Erico o "achou um mal-humorado no trato pessoal" (BARROS, 1996, p. 1).

No que se refere à passagem de ideias do próprio Erico para personagens de suas obras, como afirmado por Minchillo, era do projeto do escritor gaúcho transformar certas personagens em porta-vozes de suas percepções. Se em $O$ senhor embaixador, era por meio do professor

${ }^{12} \mathrm{O}$ tema do racismo também fora problematizado por Erico em O senhor embaixador, a partir da personagem Glenda Doremus. 
Leonardo Gris, em O prisioneiro, porta-voz de Verissimo será a professora, quando esta, em diálogo com o tenente, expõe certos vezos em relação à guerra e à própria modernidade trazidas pelos compatriotas do tenente àquelas terras, numa clara denúncia do choque identitário provocado de maneira quase imposta por um povo a outro; como assim se expressa ao tenente: "Vocês, quero dizer, os seus compatriotas, inventaram, industrializaram e transmitiram ao mundo esse hábito de viver contra um doce fundo musical, tornando tudo de certo modo parecido com o cinema" (VERISSIMO, 1967, p. 64), e mais especificamente à guerra travada no Vietnã: "se deixarmos de lado o barbarismo nazi, terá havido neste século guerra mais 'exagerada' e absurda do que esta em que vocês se meteram e que não poderão ganhar... e não querem perder?" "13, e em um tom de ironia, que na visão de Jenny responde como isotopia metafórica ${ }^{14}$, prossegue: " $\mathrm{Na}$ minha opinião, vocês se transformaram, talvez sem perceber, em modernos Inquisidores que a ferro e a fogo querem impor aos hereges a sua Salvação e o seu Céu" (VERISSIMO, 1967, p. 66), isso porque "essa espécie de paz que seu país oferece aos chamados povos subdesenvolvidos, uma paz policiada, colonial, digamos, romana... Na minha opinião, no caso deste conflito, vocês podem ser comparados com um Bom Samaritano desastrado", afinal, "fere e até mesmo mata a pessoa que pretende socorrer" ${ }^{\prime 15}$.

A professora chega a ser mais incisiva quanto ao choque das ideologias e dos regimes políticos, quando infere que: "De acordo com a teologia política de seu governo, tenente, este país asiático corria e corre o perigo mortal de sucumbir ao Diabo Vermelho. E aqui estão vocês como modernos samaritanos armados dos engenhos mais terríveis de destruição", ao que o tenente, por sua vez, não sendo militar mas civil, concorda quanto à intervenção de seu país em terras alheias: "Fomos péssimos colonizadores. Egoístas, orgulhosos, gananciosos e sem escrúpulos. Trouxemos para cá, entre outras coisas más, um dos piores símbolos de nossa decantada civilização: a guilhotina..."16. A fala da professora tem relação direta, em termos de contraposição, com a do coronel, que em diálogo com o major (que parece, em certos pontos, concordar com o discurso da professora), defende a intervenção naquele território como "uma missão civilizatória", porque "Está ao nosso alcance salvar da miséria, da doença e da ignorância este e outros países do mundo igualmente subdesenvolvidos"17, frente àquele povo, constituído, segundo sua visão irônica, por "moluscos, lombrigas, sanguessugas" observa, em nível de narrativa, que tal "projeto civilizatório (neo)colonial, que sempre escamoteou interesses econômicos e políticos, gerava, sem mais disfarces possíveis, a barbárie", fato este que fazia com que o tenente desejasse, embora escapando da questão racial de sua própria terra, o retorno a ela, a fim de fugir do caos da guerra. Aliás, aqui, mais uma crítica de Erico Verissimo acerca do sistema neocolonial e à própria questão racial, encontrando no tenente, que é negro, um "processo de autorrejeição e um esforço de desidentificação" 19 .

O diálogo entre o coronel e o major, e o do tenente com a professora, dentro do próprio romance, podem ser vistos como uma isotopia, que, na visão de Jenny (1979, p. 27), permite manter a coesão do texto, "como a compensar a deficiência da estrutura narrativa e a oferecer uma unidade contra a multiplicidade das escritas". Isotopias em Erico poderão ser vistas, ainda, com relação Asturias, por exemplo, quando, diante do regime totalitário, há, da parte dos ditadores, tanto em $O$ senhor presidente quanto em $O$ senhor embaixador, um modus operandi em plantar falsas verdades contra os inimigos ou que representem ameaças ao regime - no primeiro romance, é a morte de Mosquito o álibi dos homens de poder para incriminar seus desafetos, no

\footnotetext{
13 Idem, ibidem, p. 66.

14 "Um fragmento textual é convocado por analogia semântica com o contexto" (JENNY, 1979, p. 35).

15 Idem, ibidem, p. 67.

${ }^{16}$ Idem, ibidem, p. 70.

17 Idem, ibidem, p. $27-8$.

${ }^{18}$ Idem, ibidem, p. 26.

19 Idem, ibidem, p. 252.
} 
segundo, a morte de Júlio Moreno; além, lógico, de haver sempre a retratação da resistência, que em Asturias está no general Canales e em Erico no guerrilheiro Miguel Barrios.

Outro ponto que permite relacionar em simetria os dois romances de Erico, e ainda na perspectiva construída pelas personagens porta-vozes da concepção ideológica do autor, encontra-se na professora, assim como fora encontrado em Leonardo Gris. Ambos expressam forte denúncia aos veículos de comunicação dos Estados Unidos, em específico os jornais, a opinião pública, que faz com que seus compatriotas pensem no papel de bom samaritano estadunidense em terras asiáticas, quando, na realidade,

\footnotetext{
Vocês estão fazendo uma guerra de terra arrasada, uma guerra total. Jogam bombas de fósforo nos matagais para descobrir o inimigo que ali se esconde. Ora, essas armas químicas destroem também as árvores frutíferas, as colheitas, o gado, os bichos domésticos e, por assim dizer, traumatizam a própria terra. E pior que isso são essas bombas napalm, que às vezes arrasam aldeias inteiras, queimando seres humanos inermes e, esses sim, verdadeiramente inocentes, pois alguns nem chegam a compreender direito o que se está passando... (VERISSIMO, 1967, p. 68).
}

Aqui, portanto, quanto a personagens que assumem a ideologia e a reflexão de seu autor, pelo menos em nível de construção, há o que se pode entender como simetria, entre os romances O senhor embaixador e O prisioneiro - relacionada, mesmo, à sua técnica narrativa.

É válido observar ainda outro aspecto da narrativa de Erico em O prisioneiro que, diferindo de Greene, ao negar certa relação direta com o predecessor, opta por não nomear as suas personagens; mais ainda: não nomeia de maneira evidente o espaço geográfico em que se desenrola a trama, embora este possa ser facilmente identificado como o Vietnã devido aos espaços alocados ao longo da fábula. Esse recurso empregado pelo escritor gaúcho impõe, não por acaso, uma reflexão sobre identidades que, em momentos-chaves, chegam mesmo a se confundirem com questões de ordem racial.

Sendo o estilo realista comum aos dois textos (o de Greene e o de Verissimo), simetria que não vista entre $O$ senhor presidente, surrealismo neobarroco, e $O$ senhor embaixador, realista, há pontos outros que permitem aproximar o modo narrativo dos dois escritores em perfeita simetria intertextual. Apesar dos pontos de vistas estarem relacionados a personagens distintos no campo fictício (em $O$ prisioneiro, é o de um tenente; em $O$ americano tranquilo, o de um jornalista), e ainda de curtas passagens alusivas a essas personagens próximas aos fronts, em geral temos uma relação indireta à guerra, como quando outros códigos se repetem, a citar o amor, a violência, o assassínio, atentados a bomba; além dos que se invertem, e que merecem maior destaque por representarem, nesse ponto de vista - com relação a Verissimo e a seu predecessor, Greene - um tipo de Kenosis, ou seja, sintoma admitido por Harold Bloom como próprio da "angústia da influência", em que a obra posterior tende a romper radicalmente com a obra anterior. Tais rompimentos, ou antes, inversão de códigos, podem ser explicados pelas escolhas operadas em Verissimo com construções que vão desde o ponto de vista narrativo ao ideológico.

A começar, os dois romances são de aventura de guerra, porém diferem radicalmente quanto às suas construções ideológicas. Como dito anteriormente, em O prisioneiro há em evidência o constructo do racismo, relacionado diretamente ao protagonista, já em Greene o tema de fundo, problematizado pelo jornalista Fowler, é o envelhecimento, que norteia algumas reflexões e condutas da personagem. Se o desejo também está presente nos dois romances, suas operações, porém, também diferem de modo radical, pois, se a relação amor e guerra em $O$ americano tranquilo parece mais pura, já que Fowler demonstra de maneira clara seu desejo de posse por Phuong, frente a uma situação de divórcio que se encaminha com a sua ex-esposa; em $O$ prisioneiro, o desejo do tenente por K. não é o de posse, mas, em certos pontos, até mesmo de carinho e de carne, embora com o tempo prevalecesse aquele. Diferentemente a Fowler, o tenente é casado e há momentos na narrativa que, apesar de ter fugido das questões raciais em 
seu país de origem, demonstra vontade em retornar para a família a fim de esquecer o caos da guerra no Vietnã.

Outro ponto que também demonstra uma clara inversão do código pode ser visto a partir do que Todorov entende como gramática da narrativa. Se em $O$ americano tranquilo ocorre a retomada do equilíbrio inicial, representada em Fowler e Phuong, principalmente após a morte de Pyle; em $O$ prisioneiro, o que ocorre é justamente o contrário, o desequilíbrio e a transgressão da situação inicial, quando da morte do protagonista, o tenente.

A visão dessas relações intertextuais permite colocar as obras aqui analisadas dentro de um circuito de influências e, até, de inscrição em um dado contexto e tipo de gênero utilizado e propagado pelos homens de letras da América Latina. O caso de Greene, porém, mais afastado aos demais, relaciona-se, no entanto, à própria fabulação de Verissimo, que toma a obra como predecessora e encaminha $O$ prisioneiro ao conjunto de romances internacionais dos quais se ocupara em certa fase de vida.

Fica aqui ilustrada a importância da intertextualidade na compreensão do texto ficcional, não como parte, mas como fundamento à sua própria estrutura e significação, cuja construção, como lembrou Jenny, a partir de Tynianov, participa de uma rede dupla de relações diferenciais, e que aqui se demonstrou, sendo a primeira aquela a partir de obras pré-existentes, e a segunda, por meio de sistemas de significação não literários, como admitidos os posicionamentos ideológicos de Erico Verissimo. Não foi por acaso que Jenny (1979, p. 13), ao ler Julia Kristeva, e reconhecendo, mais do que a duplicidade dessa rede de relações um mosaico de citações, afirma que "o texto literário passa a ser o lugar de fusão dos sistemas de signos ordinários das pulsões e do social". Só assim ele se constrói e se torna legível, afinal, em sua operação, "a intertextualidade designa não uma soma confusa e misteriosa de influências, mas o trabalho de transformação e assimilação de vários textos, operado por um texto centralizador, que detém o comando do sentido" (JENNY, 1979, p. 14).

\section{REFERÊNCIAS}

ASTURIAS, Miguel Ángel. O senhor presidente. Tradução de Antonieta Dias de Morais. São Paulo: Editora Brasiliense, 1967.

BARROS, André Luiz. O panfletário irreverente. Jornal do Brasil: caderno B, Rio de Janeiro, p. 1, 2 jun. 1996.

BORDINI, Maria da Glória. A materialidade do sentido e o estatuto da obra literária em $\mathrm{O}$ Senhor Embaixador, de Érico Veríssimo. In: ZILBERMAN, Regina et al. As pedras e o arco: fontes primárias, teoria e história da literatura. Belo Horizonte: Editora UFMG, 2004, p. 199-275.

CARPEAUX, Otto Maria. O romance como poema e a ditadura como realidade. In: ASTURIAS, Miguel Ángel. O senhor presidente. Tradução de Antonieta Dias de Morais. São Paulo: Editora Brasiliense, 1967. p. 9-13.

GREENE, Graham. O americano tranquilo. Tradução de Brenno Silveira. São Paulo: Abril, 1974.

JENNY, Laurent. A estratégia da forma. In: Poética: revista de teoria e análise literárias: Intertextualidades. Tradução de Clara Grabbé Rocha. Coimbra: Almedina, 1979. p.5-45. 
MUKAROVSKY, Jan. Obrigações da ciência literária em relação à literatura mundial contemporânea. In: TOLEDO, Dionísio (org.). Círculo linguístico de Praga: Estruturalismo e semiologia. Tradução de Zênia de Faria et al. Porto Alegre: Editora Globo, 1978. p. 310-14.

SAID, Edward. Cultura e imperialismo. Tradução de Denise Bottmann. São Paulo: Companhia das Letras, 2011.

SOMMER, Doris. Pelo amor e pela pátria: romance, leitores e cidadãos na América Latina. In: MORETTI, Franco (org.). A cultura do romance. Tradução Denise Bottmann. São Paulo: Cosacnaify, 2009. p. 309-33.

TODOROV. Tzevtan. As estruturas narrativas. Tradução de Leyla Perrone-Moisés. São Paulo: Perspectiva, 2006.

VERISSIMO, Erico. O prisioneiro. Porto Alegre: Editora Globo, 1967. O senhor embaixador. 22. ed. São Paulo: Companhia das Letras, 2009.

Recebido em 1/10/2017

Aceito em 23/3/2018 